\title{
Community food work as critical practice: A faith-based perspective through narratives
}

\author{
Rebecca Ligrani ${ }^{a *}$ and Kim Niewolny ${ }^{\mathrm{b}}$ \\ Virginia Polytechnic and State University
}

\begin{abstract}
Submitted October 10, 2016 / Revised February 21 and March 28, 2017 / Accepted June 13, 2017 /
Published online September 26, 2017

Citation: Ligrani, R., \& Niewolny, K. (2017). Community food work as critical practice: A faith-based perspective through narratives. Journal of Agriculture, Food Systems, and Community Development. Advance online publication. http://dx.doi.org/10.5304/jafscd.2017.074.001
\end{abstract}

Copyright (C) 2017 by New Leaf Associates, Inc.

\begin{abstract}
Community food work is a framework for understanding the interconnections and complexities of food systems issues such as farm sustainability, food access and health equity, environmental resiliency, and social justice. An emerging yet overlooked perspective of community food work is the role of faith-based organizations and practitioners. In this single case study of six faith-based practitioners focused on urban food security in Virginia, we use narrative inquiry to explore how they understand and perform their community food work from a faith-based and social justice context. Our methods included interviewing each practitioner to create stories of their everyday work, researcher-participant analysis of those

\footnotetext{
a * Corresponding author: Rebecca Ligrani, Department of Agricultural Leadership and Community Education, Virginia Polytechnic and State University; becca.ligrani@gmail.com

b Kim Niewolny, Department of Agricultural Leadership and Community Education, Virginia Polytechnic and State University; 282 Litton Reaves Hall; Blacksburg, VA 24060 USA; +1-540-231-5784; niewolny@,vt.edu
}

stories, and a collective reflection session of the group's narratives. The final narratives not only point toward specific social justice values and practices aimed at addressing race and class inequity in the food system as significant elements of their community food work, but also created new space for practitioner reflection and discovery of the way white privilege and class-based assumptions can be uncovered and challenged in the work itself. In this way, the research describes what community food work looks like through a faithbased lens, while also showing how storytelling and narratives can be used as an approach to create possibility for critical reflection about power and privilege in our everyday practice. We conclude with suggestions for using storytelling and narrative inquiry in similar food system contexts as a strategy for community change.

\section{Keywords}

Community Food Work; Critical Consciousness; Faith-Based Organization; Food Security; Narrative Inquiry; Whole Measures for Community Food Systems 


\section{Introduction and Literature Review}

Wickedness of Food Insecurity in the U.S. For many, food insecurity is a wicked problem that brings together various explanations as well as approaches to addressing the issue (Hamm, 2009). Descriptions of what is defined as food security range from household to community perspectives based on policy, grassroots, and academic influences (see Hamm \& Bellows, 2003). For instance, the U.S. Department of Agriculture (USDA) deems households with members who face times where they do not have access to enough food for an active, healthy life as food insecure (Coleman-Jensen, Nord, \& Singh, 2013). For others, food security work emphasizes food system change with the goal of developing healthy communities and local capacity that addresses community needs (Abi-Nader et al., 2009). According to the USDA, in 2016 food insecurity affected approximately $12.3 \%$ of households and has not significantly declined since a 2011 high of 14.9\% (Coleman-Jensen, Rabbitt, Gregory, \& Singh, 2017).

Since the early 1900s, many food-insecure Americans have avoided hunger by accessing government entitlement programs, also called the food "safety net" (Poppendieck, 1998; Winne, 2008). These subsidy programs—-such as the Supplemental Nutrition Assistance Program (SNAP) and the Special Supplemental Nutrition Program for Women, Infant, and Children (WIC)—attempt to close the gap between some of those with low incomes and the marketplace (Fisher, 2017). However, these programs were downsized during the Reagan administration (Winne, 2008). As the federal government withdrew funding from these programs, charitable organizations stepped in to close the hunger gap. This move signaled the rise of institutionalized emergency food, primarily managed by nonprofit organizations and faith-based institutions (Winne, 2008).

While entitlement programs and charity reduce hunger, their entanglement in various political agendas and lack of focus on the underpinnings of hunger-poverty and inequality-generally leaves these programs as less-than-sufficient stopgap measures
(Poppendieck, 1998; Winne, 2008). Although these channels were intended to be temporary, they have become essential resources, initiating greater criticism of the industrial anti-hunger charity system (see Fisher, 2017). For instance, Cadieux and Slocum (2015) critique anti-hunger charity as a patronizing system of programs that do not seek systemic change. Anderson (2008) argues that the lack of public participation and decision-making in these programs, and the industrial food system altogether, perpetuates food insecurity. Furthermore, Fisher (2017) asserts that anti-hunger charity does not hold businesses accountable for low wages, worker exploitation, benefits cuts, and more. The limits and insufficiencies of charities do not go unnoticed by their staff, as Winne (2008) describes from his first-hand experience with food bank operators in Hartford, Connecticut.

\section{Faith-Based Organizations and Food Security}

Faith-based organizations (FBO) provide a space for members to express their faith through the missions and activities of the organizations' programming (Schneider, Wittberg, Unruh, Sinha, \& Belcher, 2011). According to Todd (2012), FBOs have played a role in development efforts by creating supportive community settings that may also help reduce social marginalization of historically underserved communities. Although the work of FBOs has been varied and at times controversial, we point to three primary reasons that faith-based organizations are involved in food systems work. First, there is an historical connection between faith and food because food serves faith-based functions across several religions (Mann \& Lawrence, 1998). Second, many faith traditions have a philosophy to care for the poor (McGovern, Dole \& Messer, 2005). Third, faith-based organizations generally have social and cultural capital that make them adept at engaging in social justice work (Rosenberger, Richards, Nevin Gifford, \& Gossen, 2006; Todd, 2012); research suggests that high levels of social capital can increase a group's success at food systems change (Crowe \& Smith, 2012).

According to Dixon (2015), FBO staff and volunteers are candidates for social justice work. 
They may advocate for social change by inquiring into and challenging the assumptions that those accessing emergency food fit the master narrative of being "too lazy to work" or "suffering a temporary hardship," instead realizing that there are structural inequities that systematically disadvantage groups of Americans. Examples of faith-based organizations that perform social justice and advocacy work include Come to the Table in North Carolina, ${ }^{1}$ the Baltimore Interfaith Food and Farms Program (Johns Hopkins Center for a Livable Future), and Ecumenical Ministries of Oregon, ${ }^{2}$ all of which are dedicated to supporting the development of socially and environmentally just food systems. Each of these organizations has a commitment to long-term food systems change and equitable structures that engage people across racial and class lines.

\section{Food Security and Community Food Work}

Alternative food discourses and their respective food movements incorporate issues of human rights, sustainable production, human health, and democratic policy change that generally counter the corporatization of our agricultural and food systems. To some scholars, while social change is the goal, these alternative food movements have created spaces that build social, physical, and financial barriers for low-wealth and historically marginalized groups (Cadieux \& Slocum, 2015; Guthman, 2008; Slocum, 2007). We find Slocum's $(2006,2007)$ conceptualization of community food work as the prime way to infuse the alternative food movement with a more critical perspective on the complexities of food systems change.

According to Slocum (2006), community food work is food systems work that promotes fair prices, sustainable practices, and accessible, affordable, culturally appropriate, healthy food for all people. There are numerous intersecting practices that fall within these bounds, but they do not necessarily value inequity in food systems as a serious obstruction of justice. Community food work is naturally political and even criticizes alternative food movements (e.g., sustainable

\footnotetext{
${ }^{1}$ http://rafiusa.org/cttt/

2 http://www.emoregon.org/food farms.php
}

agriculture, local food, animal rights) for their failure to acknowledge institutionalized biases in the food system, especially biases rooted in race, class, and gender politics (Guthman, 2008; Slocum, $2007,2006)$. In the context of community food work, a recurring trend in U.S. history is the marginalization of minorities, especially people of color, which has resulted in a disproportionate rate of food insecurity now present in households within those communities (Alkon \& Agyeman, 2011; Ramírez, 2014). In 2016, homes with a Black head of household had a food insecurity rate of $22.5 \%$, whereas homes with a white head of household had a rate of 9.3\% (Coleman-Jensen, Rabbitt, Gregory, \& Singh, 2017). Anderson (2008) and others also argue that the U.S. agrifood system perpetuates food insecurity through the lack of participation in political decisions about food, elimination of traditional foodways, and environmental degradation that affects the sustainability of land and water resources.

In this research, we focused on community food work as one illustration of food systems change from a faith-based perspective. The increase in faith-based community food work organizations prompted us to explore (1) what values for pursuing community food work are present in everyday practice; (2) to what extent practitioners perform community food work from a social justice perspective (i.e., one that brings issues of power and privilege to the forefront of practice); and (3) how storytelling and narratives of community food work help create space for critical reflection about the ways in which we can better "see" and enact socially just community change. In the remainder of the paper, we illustrate the growing shift from faith-based charitable work to community food work to begin addressing these questions. We also highlight the ways in which practitioners understand and address the issue of social justice as a radical change in their efforts to create meaningful and inclusive food systems change. We focus on a single case study of six faith-based practitioners addressing urban food security in Virginia. From this perspective, we use narrative inquiry as a methodology to explore how these practitioners understand and perform their community food work from a faith-based and social justice context. 
Our methods included interviewing each practitioner to create stories of their everyday work, researcher-participant analysis of those stories, and a collective reflection session of the group's narratives. We begin with a description of the conceptual framework that guides our research and findings.

\section{Conceptual Framework}

We used a threefold conceptual framework in the design of this study. First, we drew from Slocum's (2006, 2007) concept of community food work, which focuses on the integration of such themes and domains as farm sustainability (e.g., farmer support, market linkage, and education), nutrition education (e.g., health and diet-related disease prevention), environmental sustainability (e.g., ecology and land-based sustainability), and social justice (e.g., farmworker/producer rights and hunger/food insecurity). This is reinforced by Tanaka, Indiano, Soley, and Mooney (2015), who describe community food work as simultaneously a community organizing process for concerned citizens, activists, and professionals to create new food systems, and a goal for attaining food security for their community.

We argue that locating their practice within the concept of community food work makes it more transparent and accessible for practitioners to communicate and share their complex work and the values that drive their actions (Abi-Nader et al., 2009). In this vein, we point toward a team of food security practitioners/scholars who created Whole Measures for Community Food Systems (CFS) to plan, evaluate, and talk about community food work and holistic food systems change. We used Whole Measures CFS as the second piece of our conceptual framework because it places a reflective lens on the work by focusing on practitioner dialogue around six fields and practices: justice and fairness, strong communities, healthy people, vibrant farms, thriving local economies, and sustainable ecosystems (AbiNader et al., 2009). These fields and practices are grounded in the values and value systems that inform the work of the practitioners and the communities in which they operate.

The third piece of our framework is the act of critically reflective practice, a concept from the field of adult education. ${ }^{3}$ According to Brookfield (2001), critically reflective practitioners are those who take a mindful and purposeful approach to their educational work and seek to name and question the power relations that inform and govern educational actions and agendas. This approach is similar to Freire's (1972) critical pedagogy, in which critical reflection and dialogue about one's practice are sources of new ideas and possibilities for socially just ideas and actions. Thompson and Pascal (2012) and Cervero and Wilson (2001) further help us see how educational practice is a matter of negotiating the way micro and macro power structures influence our everyday decisions as practitioners; thus the role of critical reflection is important in order to "see" the way power governs educational and community change work.

We specifically used Brookfield's (1995) four lenses of critical reflection to explore the practice of community food work practitioners, framing the practice as a political act of education and social justice (Freire, 1972; Giroux, 2006). The lenses of critical reflection are (1) the autobiographical, (2) the students' eyes, (3) our colleagues' experiences, and (4) theoretical literature (Brookfield, 1995). Educational practice in this sense is the ongoing conversation between theory and reflection by the practitioner (Ford, Johnston, Brumfit, Mitchell, \& Myles, 2005; Lather, 1991). These internal and external conversations about the way community food work is understood and performed are explored from the narratives in this study.

These three concepts come together to guide our research as a holistic conceptual framework (Figure 1). The intersection of these areas helps us illustrate the ways in which our case study practitioners understand and address the issue of social justice as a shift in their efforts to create meaningful and inclusive food systems change.

\footnotetext{
${ }^{3}$ Critically reflective practice finds it roots in the German Frankfurt School, which stemmed from Marx's theories of false consciousness, commodification, praxis, and emancipation (Brookfield, 2001; Morrow \& Torres, 2002). The philosophers of the Frankfurt School built a lineage of critical social theories critiquing capitalism. Thinkers including Hegel, Kant, Marcuse, and Habermas influenced the concepts of critical reflection and the critically reflective practitioner that we incorporated into this research.
} 
Figure 1. Diagram of the Conceptual Framework Guiding this Study

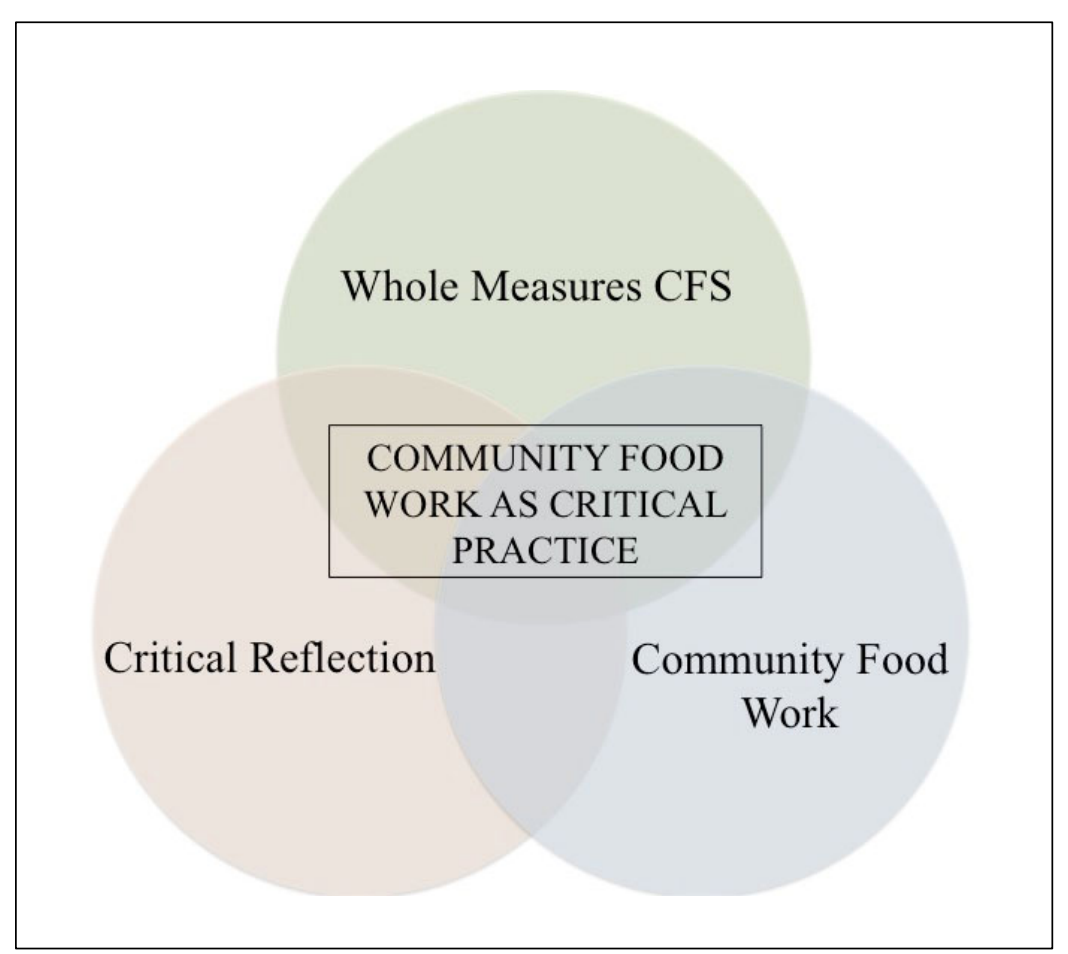

well as the material outcome of the story itself.

\section{Study Site and Participant Recruitment}

The primary researcher contacted several organizations working in the mid-Atlantic and Appalachian regions of the U.S. for a preliminary discussion about participating in the study. The executive director of Welcome Table was the first to express interest. We had several phone conversations and formally invited the organization to participate after the executive director confirmed similar interest with the staff and board. We selected this organization because of its open expression of faith in its work, its farm-and city-based programs, and its participation in city and even statewide conversations and coun-

\section{Methodology}

We designed a qualitative study and received approval from the Virginia Polytechnic and State University Institutional Review Board. We took a constructivist approach (Brookfield, 2009) for this research, which is important for two reasons. First, it placed practitioners as the experts of their own experiences and included them as co-creators of the knowledge presented in this research. Second, it allowed for new perceptions of the work to emerge as we learned throughout the story-making process. We used narrative inquiry to generate the stories with participants from this study, making them socially constructed and interpreted narratives (Brookfield, 2009). Therefore, the perspectives generated in the research are based on the social and political reality of the participants (Brookfield \& Holst, 2011).

Narrative inquiry is a qualitative research method that captures experiences and meanings from the telling and retelling of stories (Clandinin $\&$ Connelly, 2000). We use "narrative" to mean both a storytelling process and a product (Richmond, 2002). This includes treating the narrative as the process of creating the story, as cils about food systems. From these observations, it was clear that this organization is a leader in food systems work in the Virginia city in which it operates. After agreeing to participate, the executive director served as our organizational liaison to invite his staff and program partners to participate in the research. At the end of recruitment, we had practitioners from two organizations take part in the project. It was important for the partnering organization to participate in the study because they are also faith-based and play an active role in Welcome Table's flagship program. Following our IRB protocol, we assigned pseudonyms to the organizations and the participants to ensure anonymity of the participants and their organizations.

Welcome Table is a faith-based 501(c)(3) affiliated with a Christian church that engages in social and economic justice issues in a Virginia city and the surrounding region. Its flagship program is a prescription produce program, where food is grown on a 6-acre (2-hectare) organic farm and provided to program participants onsite in public housing communities as a weekly prescription coupled with health check-ups. Other programs include a youth-run farm stand that employs and 
serves public housing and low-income communities; farmer-in-residence and social-work intern programs; and myriad volunteer experiences on the farm. Each of these programs aims to fulfill the organization's threefold goals of (1) growing healthy produce for underserved communities; (2) providing experiential learning to youth and adults; and (3) linking community groups. The partner agency, Fresh Start, is a coalition that works to reduce childhood obesity and collaborates with Welcome Table to administer the prescription produce program. Table 1 describes the practitioners who participated.

\section{Data Collection and Analysis}

We implemented a three-part data collection process. First, drawing upon a process similar to Peters and Hittleman (2003), Peters, Grégoire, and Hittleman (2004), and Niewolny and D'AdamoDamery (2016), we conducted a 45 to 90 -minute in-depth interview with each participant. The interview protocol was adapted from Niewolny and Landis (2014). This instrument was designed for the Appalachian Foodshed Project Practitioner Profiles in which practitioners were interviewed using three categories of prompts: (1) background and motivations for doing this work; (2) a practice story about a specific program or project; and (3) reflections on the practice story presented.

The second point of data collection also served as an analysis through the retelling of stories. We provided each participant with their interview transcript to not only vet it for accuracy but to respond with emergent themes they found significant and excerpts to support their selections. Participant analysis was a crucial element to this study because it included participants as researchers and demanded concentrated individual reflection. We combined these participant analyses with our own analysis up to this point to plan the collective reflection session - the final piece of data collection and another piece of analysis.

Third, the collective reflective session was a time for dialogue between the practitioners as they reflected and learned about their work as a group and individually. We began the session by providing each participant with a Whole Measures CFS packet and discussing how we used the fields and practices to code the data. Next, we read excerpts from each narrative interview aloud to each other and facilitated continued conversation through a set of prompts. The reflective session allowed the retelling of stories shared in the narratives and the telling of new stories as they emerged.

The primary researcher managed all data collection and analysis. We recorded audio from all interviews and the collective reflection session, transcribed them, and uploaded them into Atlas.ti for analysis. The primary researcher coded all transcripts three times with regular input from the second researcher. We coded the transcripts using $a$ priori codes developed from our conceptual

\section{Table 1. Practitioner Roles and Demographics}

\begin{tabular}{lllll}
\hline Practitioner & Role & Age & Race & Education Level \\
\hline Eddie & Welcome Table; executive director for five years & 30s & White & Bachelor's \\
\hline Taylor & Welcome Table; farm manager for five years & $30 s$ & White & Master's \\
\hline Onyx & $\begin{array}{l}\text { Welcome Table; board chair for less than one year; board } \\
\text { member previously }\end{array}$ & $50 s$ & White & PhD \\
\hline Terry & $\begin{array}{l}\text { Welcome Table; community advocate; previous } \\
\text { prescription produce plan participant; community resident }\end{array}$ & 20s & Black & High School \\
\hline Blaire & $\begin{array}{l}\text { Welcome Table; newly hired program coordinator; previous } \\
\text { social work intern }\end{array}$ & $20 \mathrm{~s}$ & White & Master's \\
\hline Casey & $\begin{array}{l}\text { Fresh Start; childhood obesity coalition coordinator; } \\
\text { partners with prescription produce plan }\end{array}$ & $40 s$ & White & Master's \\
\hline
\end{tabular}


framework, codes identified by the practitioners through their vetting and analysis, and emergent codes. This dual inductive and deductive approach allowed us to address the guiding research questions while remaining open to other opportunities for depth and richness to emerge.

\section{Results}

We organized our findings around four primary themes. First, faith played a role at varying scales in each practitioner's work. Second, several of the fields and practices from Whole Measures CFS emerged through the practitioners' stories, primarily justice and fairness, healthy people, and strong communities. Third, critical reflection was practiced not only in the daily work of the practitioners, but over the entire course of this inquiry. Lastly, based on this reflection in the storytelling process, the practitioners uncovered and explored how power and privilege operate in their community food work.

\section{Faith-Based Practice}

Since each practitioner identified as a person of faith, we first grounded their practice in their spiritual or religious beliefs to the extent that the data allowed. The practitioners referenced faith directly 27 times during this narrative inquiry, despite only one question in the protocol directly referencing the practitioners' faith. However, there was a spectrum of significance among the participants. On one end of the spectrum, Onyx stated that her faith is the whole reason she is involved in this work:

Well I mean I go back to the faith piece. I mean I think for me that's it....I would say that many of us around this table get up in the morning knowing that we are doing this to create God's kingdom, or however we want to frame it in our heads, and that this is a hell of a lot of work and you don't do it unless you've got some bigger purpose.

At the other end of the spectrum, Taylor stated that he would be doing this work even if he were not a person of faith, simply because he loves the work.
But I don't want to act like that the reason I do what I do has anything to do with my faith as much as it has to do with just loving the work. I want to be fair. I wouldn't do it if I believed that this is the best thing that someone could be doing who really truly believed in God if I didn't really just love doing this kind of stuff.

Eddie brings a new perspective into the conversation by modeling his faith through actions rather than explicitly sharing his beliefs with others.

Faith is certainly kind of the guiding force and the reason why I do my work. We sort of as an organization probably embody that cliché, what people call the Francis idea, but I don't think St. Francis ever really said it: "Preach the gospel at all times, use words when necessary." I think for myself and Taylor that certainly drives the work we do. Not about trying to literally preach the gospel to anyone or use our work as an explicitly evangelical or evangelizing tool, but as a way to fulfill what we feel is our own obligation and desire and joy and gift and to be able to share that with others. That being said, with the exception of giving talks like I did on Sunday at a church or working with a church garden on Wednesday, I think a lot of our vocabulary is not explicitly Christian because these ideals are often broad universal ideals. They are beyond being JudeoChristian ideals. I think we also feel an obligation to make sure that the work that we do doesn't turn anyone off or scare anyone away and allows folks to all feel like they have a place at the table here. So we try to use as welcoming programs and as welcoming language as possible without trying to hide from who we are and why we do what we do. Which is a delicate balance.

This might be cliché, but again as a result of my upbringing from my parents, whether you want to look at him as a historical figure, a mythical figure, or just a figure in the faith tradition, Christ is this cool example of 
this food justice advocate, right? And it's a pretty cool model.

A primary theme of faith-based practice was the idea of being called to serve. Blaire offers this perspective from her place of faith:

I would say my faith tradition places a lot of emphasis on justice and how people of faith are called to promote justice, so I think justice and fairness and strong communities come a lot from recognizing that we have a responsibility to others and that we can't operate alone, so kind of looking at the body of believers and seeing that encompasses a lot of people. So knowing that we can't only look at taking care of one aspect — so our own community or our own family

—and kind of seeing that all as interconnected so you can't see your own family without seeing another family.

The role of faith cannot be separated from the values incorporated in one's community food work, nor is faith the only source of practitioners' values. Keep this complexity in mind while reading and reflecting on the excerpts that follow.

\section{Values from Whole Measures for Community Food Systems}

Every field and practice from Whole Measures CFS emerged at some point throughout the narrative, although some were more prevalent than others. Justice and fairness, strong communities, and healthy people were the three fields and practices most heavily discussed. Following these were vibrant farms, thriving local economies, and sustainable ecosystems. Perhaps more revealing than what fields and practices were evident, is how these fields and practices are performed. Justice and fairness, strong communities, and healthy people were predicated on building and leveraging relationships. This piece of the work permeated our entire inquiry. Building relationships set the stage for practitioners and participants to develop trust and learn from each other, community members to meet each other and nourish their health (social, emotional, mental, spiritual), community members to be connected to other resources, and partnerships to be created to deliver more holistic and effective programs. Blaire identified strong relationships as one of her own themes:

I think this is a core value for me, because strong communities and strong relationships are both developed over time for everyone-and are often neglected when we think about community needs. I also believe that these are essential to sustainable change and working towards social justice. Building a sustainable food system doesn't mean a lot unless there are groups of people in [the] community that are present and committed to supporting and participating in the system....As far as what makes them strong-I think that is harder to identify. I think I personally feel like I have strong relationships or am in a strong community when there is a sense of support and validation, and [a] perception of agency over circumstances or surroundings.

Terry sees a daily impact of the prescription produce program on relationships among the residents it serves.

I've seen relationships develop. Some of our clients didn't know anybody. A couple of them didn't come outside- they didn't get with anybody. And now they have a couple friends that they deal with. So I enjoy seeing that.

Healthy people is a theme that arose often out of Casey's narratives. There is the obvious connection here to the field of bealthy people from Whole Measures CFS, and it is evidence that although we are separating faith from the fields and practices in theory, they are inseparable in practice. Casey's excerpt from the collective reflection session summarizes the role of faith in her work and the significance of the body as a gift:

I had mentioned that I think people of faith shouldn't accept the world the way it is, but that they should recognize and have 
commitment to making the world a better, more vibrant, dynamic, just, fair place. So that's something that faith motivates me to action-to not accept the current reality. I also think from the faith perspective just that the body is a gift and that there's so much joy to be found in the body, but that's a challenge for so many people. And I think what the core values for me are just that food is so essential—so fundamental to people's health, happiness, spirituality, sense of community, and that's probably why all of us choose to work in this area, because it's so core to people's wholeness and wellness.

The theme of sustainable ecosystems emerged more in the collective reflection session after we provided the practitioners with the Whole Measures CFS framework. Eddie stated that this was important to him for the theological values of creation care and stewardship. Taylor also found meaning in these values and felt a responsibility to be the voice for those organisms without one, such as microbes in the soil. In the excerpt below, Taylor shares how he drew inspiration from feminist Christian theologian Sallie McFague, who wrote extensively about the earth as a metaphor for God's body.

So her [Sallie McFague] thing was that our primary vocation as a people is outlined in Genesis and that is to serve and to keep the earth. It's been translated a lot of different ways, but for her our vocation as a people is to do that. When I read it the first time I remember thinking, "You know one of the only ways I can think of for me to be able to do that is through growing food for people."

\section{Critical Reflection on Practice}

We sought for this research to facilitate critical reflection and explore how the practitioners reflect on their practice. Each lens that Brookfield (2001) identifies (autobiographical, students' eyes, colleagues' perspective, theoretical literature) is present in the practitioners' community food work.
The most common form of reflection our participants in this study perform is autobiographical reflection, but the group also references literature, makes occasional time to reflect through their colleagues' eyes, such as in staff meetings, and through their participants' eyes in conversation and program evaluations. The three points of reflection we facilitated were the (1) narrative interview, (2) participant analysis, and (3) collective reflection session.

Their reflections on race, specifically white privilege, demonstrate their critical awareness of inequity within food systems and other socioeconomic systems. The hegemony of traditional charity and class-based assumptions were topics of scrutiny for the practitioners too. A critical perspective emerged from Onyx's interview, as demonstrated below.

I think ideally we all envision, and I'm sure we have different visions, but it involves neighborhoods that have enough to eat; communities that everybody has enough to eat. Everybody has good food to eat and it's not brought in on a food bank truck and given away, or people don't have to go stand in line and fill out paperwork-do degrading things just to get good food or just to get food, period. Sustainable change would somehow turn all of that upside down, and it's all wrapped up in poverty, it's all wrapped up in racism, and those things are not solved by a food stand, unfortunately. So as wonderful as what we're doing is, it's a long way from making real systemic change, which is eliminating poverty, which is making the playing field fair, which is having a quality education not dependent on your zip code, having a safe place to live. I'm not sure that food and agriculture [practitioners] can make that change, but I think we can partner with enough other groups and enough other people and citizens and neighbors who together maybe we could start to turn those things around.

The excerpt from Eddie below gives us a glimpse into how he makes sense of himself and 
his programming in a different cultural space, and how he addresses this friction in hopes of creating a safe, respectful space for dialogue to recognize difference and sameness.

To start by saying, "We're all going to go around and say a healthy food that we really feel good about liking and an unhealthy food that we really like a lot as well." That sort of creates open spaces for equity and saying, "Hey we're all in this together, we all have a unique relationship with food." Which for me is hovering between that space between acknowledging difference and saying, "Hey I want to get to know that difference" and then also being able to use that in a disarming way and say, "Hey because it's food and it's unique and individual, it's personal, we can just talk one on one. This is not just me making any assumption about you or your culture, or you making any assumptions about mine." This isn't a black guy saying, "I can't possibly have anything in common with what a white guy eats," when we realize at the end of the day it's just personal.

Beyond fostering greater personal fulfillment, reflection has pragmatic implications on one's practice. Here, Casey explains how she makes decisions about what work to pursue by checking in with her values.

I feel like we're just inundated all the time with more and more possibilities and they're all exciting and you want to do all of them, but you can't do all of them well. I can't, so maybe for me it's keeping these guiding principles somewhere visible so I'm reminded when a new opportunity comes I can be like, "Does this fit with what I care about? Does this further what is most important to me or us as an organization?” Just a check. It feels like we're just trying to figure out one thing when we're trying to start another thing when we're trying to follow up with another thing we didn't finish. So values and guiding principles are impor- tant, and I think I can do a better job of checking in with those more often.

Eddie found a new way to reflect on his work when he was introduced to a new way of framing cultural competency. He acknowledges that he is an outsider in the communities he serves and makes no pretense of knowing exactly how to relate.

Somebody used the phrase cultural humility for me, which is a whole area of research that I wasn't even really aware of, even though it's an area that what they're talking about makes perfect sense to me, but I never had a word for it before. I kept looking at it through the language and lens of cultural competency, which I think there's still something to. I think they can be separate and both valuable. But that was a big "aha" moment to me, was to stop thinking about how can you make sure that your programs are totally understanding of this unique identity of this specific neighborhood, this specific culture, and how can you be more reflective on your role as an outsider and that all the research and planning and focus groups in the world are never going to make you understand what it's like to live in poverty, what it's like to live in the south side of this city or anything else. So how can we have that humility and reflectiveness built into our programs?

In this next excerpt from the collective reflection session, Blaire expresses her desire for more time for reflection, which was a common theme among the practitioners.

I think it's really easy for your week to all of the sudden become a to-do list so then you stop thinking about why you're doing your work, so then your work starts going in a different direction. Then at the end of the week you're kind of like, 'Wait, I don't even remember what the point of the program is." You're just like, "I just need to get this produce out!” You forget, “Oh, I'm doing 
this because it's a justice issue." So you kind of forget the whole right and privilege framework. I think it would definitely be helpful to start checking in with that more often...

These and other remarks indicate the absence of critical reflection afforded in practice as well as the potential fruits it can yield. The following interaction from the collective reflection session demonstrates the open peer-to-peer conversations that can enhance understanding and appreciation for one another, and lead to explaining intentional organizational choices.

Casey: Just getting people excited and exuberant about the possibilities of good food and then changing the environment so that they can act on that excitement, that commitment, and desire.

Taylor: To me that sounds so much more difficult than growing the food. Because I know where my skills are.

Onyx: You don't want me at the farm.

Terry: No, first bug I'm gone. Hot, rain, you got a tough job on you.

Blaire: Well, you know how you were talking about not feeling connected or not feeling like the program stuff is within your scope? That's totally me at the farm. I'm like, "Wow, we grow a lot of stuff out here!" Even if it's just lettuce.

Eddie: I do think that's a part of our organizational goal or truth that we try to acknowledge, and we've done more and more of that I think in the last year, which is as an organization having people that have very different skill sets, that can do what they do very differently knowing that it's very complex problems.

\section{Revealing Power in Community Food Work}

The stories additionally illustrate how practitioners challenged dominant power structures in their work. The group of practitioners specifically refer- red to white privilege, class-based assumptions, and charity throughout their stories and group reflections. White privilege surfaced the most frequently as a concept the practitioners were wrestling with themselves and something they wanted to bring to light within the wider community. The excerpt below from Blaire's narrative demonstrates her acute awareness of her privilege, and the struggle it still presents to her on a daily basis at work.

I think definitely the privilege part of having to come to terms with like, "I'm a privileged white girl that's trying to do good things at the right communities" is really challenging. I mean in this city no matter what underserved community you're part of, it's probably not a white community, which was really challenging because coming from a more rural place I identified with a lot of the communities I was serving.

Eddie offers a similar perspective and a critical awareness of biased systems that have afforded him his privileges.

So I have been lucky and blessed not only to have every advantage in my backpack, but to also be able to see that that's not an accident. That why I'm here is not an accident and that there are systems propping me up that allow me to be here that as a result I feel a responsibility, when able, to be a part of dismantling those systems, and creating just, verdant, and equitable communities, to use the NPR Foundation.

The recognition of difference and white privilege came from the Welcome Table program participants as well, although they may not have labeled it as such. Furthermore, the data below comes from the practitioners and not Welcome Table's participants, so it is impossible to draw strong conclusions about their criticality. Terry and Onyx, respectively, provide glimpses into the consciousness-raising effect that Welcome Table's programs have on youth. 
The little children they really enjoy it. They're like, “Those people are rich!" Do you know that she has a house?" Even though the program is mainly about vegetables, just to see people from other places is great for them.

I think that people have to get angry. I work with a lot of teenagers from the Southside and Northside from the housing projects, and they're not angry. They don't realize how unfair it is. Some of them do. Actually some of them really do, but they're a small number.

Essential to revealing hegemonies is pushing oneself out of one's comfort zone. By engaging with these new experiences, practitioners are learning about themselves and their boundaries in their practice. One of the benefits of doing the work is the ability to push those boundaries and be better because of it, as reflected through Casey's excerpt below.

I think our involvement is not just to help others, but to help ourselves become compassionate and more patient and more aware and conscious. I don't see this work just to help others. I feel like I'm also helping myself and my family_all of us be better.

Similarly, Onyx acknowledges how worthwhile it is to push the boundaries of comfort as she was compelled to make change.

It has to be hard....We have to get out of our comfort zone, and I guess I can't make anybody else change, but I have to figure it out for myself. And then the path just started opening. I can't say that I specifically sought anything out or did anything, I just said, "Yes" to things that got put in my path, and so this organization was sort of my baby step in that direction. They were dealing with those hard issues, and it wasn't too scary, you know? I didn't have to go alone into the housing projects, I didn't have to get to know people too intimately, but it was a step in the right direction and it gave me a little bit of awareness that I didn't have before. It just helped me start learning.

Acknowledgement of such a pervasive power does not remove its ability to dictate social circumstances. However, it is an important first step to reveal and name the way power governs our community food work in the everyday sense. These stories illustrate how practitioners understand the ways in which their daily practice is influenced by their assumptions, which, if not addressed, can unwittingly influence their practice. To read the full narratives from the research, see Landis (2015).

\section{Discussion}

Community food work and its emancipatory potential are underexplored compared to other, long-standing food systems discourses, such as food security and food sovereignty. In this study, we frame community food work as critical practice. Specific aspects of community food work that resemble critical practice as community development include an asset-based approach that draws upon the talents of individuals in the community (Mathie \& Cunningham, 2003), building leadership and capacity from within the community (Anderson, 2008), and creating collective movements and institutions (Brookfield \& Holst, 2011). From an assets-based perspective (see Emery \& Flora, 2006), we argue that community food work is a space for learning, especially through storytelling. Telling one's own story and hearing colleagues' stories may expand our practitioner perspective and help us navigate new ideas, roles, and opportunities for socially equitable outcomes. Through their efforts to build and nurture relationships, provide public housing communities with the resources to access produce, and create leadership from within those communities, the practitioners in this study are working to raise what Freire (1973) refers to as critical consciousness. In other words, there is the potential within community food work to consider one's own thoughts, implicit biases, and assumptions that undergird not only the work, but also one's participation in the larger social context of food security and social justice. This reconsideration allows for new possibilities to emerge. 
While the activities of their community food work are similar to countless organizations, these practitioners' faith-based approach, combined with their critique of structural inequity, elevate their practice as an informative window into community food work from a faith-based and social justice context. Much of the work they do would fall under Guthman's (2008) characterizations of nascent food justice work, including growing fresh produce, providing it at below-market prices, and educating residents about the food. This narrative inquiry reveals that there is positive potential in these projects and that they are not necessarily creating patronizing relationships. Guthman (2008) names the problem in many of these endeavors as the "effect of white desire to enroll black people in a particular set of food practices" (p. 433). The practitioners seem to be countering this by using their programs as a venue for dialogue and relationship-building, and through their constant effort to consider the perspectives of program participants. However, we make this claim tentatively, since a far deeper inquiry would be needed to draw a more informed conclusion.

The practitioners in this research know their work is not easy, but they do not allow themselves to become paralyzed in the struggle. Rather, they seek to support their communities by finding the positive and possibilities for hope. Peters, Grégoire, and Hittleman (2004) emphasize how important it is to practice a pedagogy of hope, and we see this pedagogy embodied in the practitioners' stories. Niewolny and D'Adamo-Damery (2016) relate this need for hopefulness directly to learning for food systems change, emphasizing the possibilities and strategies in our everyday meaning-making through story, which can humanize and bring dignity to the work itself. In practice, hope can come from the small victories that encourage and give life to the sometimes tumultuous and conflicting moments of community food work. The commonality of faith to each practitioner in this study likely contributed to the bonding social capital of the group (Emery \& Flora, 2006).

On a hopeful note, Slocum (2007) suggests that practitioners move past critiques of neoliberalism and capitalism to look for the possibilities offered by community food work. She wishes to see how racial difference and connection can be better understood through these practices. The narratives do just that. They help us understand how messy and complicated, yet deeply rewarding, the practice of community food work is at the everyday level. They also show us where the tensions lie, pointing toward the spaces that could lead to harmful actions in our practice for food systems change (Slocum, 2007). In this way, despite the practitioners' criticisms of charity work, they see the present need for it and are hopeful that their work will diminish that need for future generations.

There are myriad challenges to building community food systems. Community food work is premised on critiquing and transforming the current agrifood system into more just and equitable systems. Faith-based organizations are integral players in this work. This study has demonstrated how in one case they actually conduct the work with a critically reflective practice in mind, and hope to continue that reflection as a result of sharing their stories of work. In conclusion, this narrative inquiry was not meant to raise a certain set of practices as the gold standard for community food work through a faith-based lens. Instead, the stories indicate how the work is messy, challenging, and never complete. The stories create space for critical engagement with such complexity in hopes of creating new and just opportunities in the future.

\section{Recommendations for Research}

While our approach was productive in meeting our research goals, the interviews and reflection sessions we used could be arranged using different techniques to stimulate further reflection; we see space here for creative approaches to organizing reflection individually and collectively. To expand upon the narrative methods from this study, we suggest using an adapted version of Stephen Brookfield's Critical Incident Questionnaire to begin a collective reflection session (Brookfield, n.d.). This is a straightforward start, using only a few questions to elicit reflection on critical moments, such as "aha" moments or meaningful moments. Furthermore, techniques and steps used in Appreciative Inquiry (Whitney \& Cooperrider, 1998) would provide an assets-based approach to 
engage practitioners in autobiographical and peer reflection. These steps would include interviewing a colleague about a positive experience and then reporting back to the larger group. Appreciative Inquiry may also help to bridge the divide between silos of work because it builds a collective vision and uses a group process to choose steps to achieve that vision. Additionally, future research could incorporate even more participant analysis. Lather (1991) and hooks (1994) suggest such methods as an emancipatory approach to teaching and research. We recommend providing the participants with several opportunities to engage in analysis and meaning-making. A process could be designed where each party would build upon previous analyses, such that both are active subjects in the creation of the knowledge (hooks, 1994). This process would improve the reliability of the study as described by Lather (1991). Although these additional reflective methods were outside the scope of this study, they would likely yield rich insights into more cases of community food work.

Enhancing practitioner perspectives with program participant and community member perceptions could further illustrate the concepts of critical consciousness-raising according to Freire (1973). Richmond (2002) explains that transformative learning can occur when groups come together to critically reflect. Understanding how community food work can raise critical consciousness was not an intent of this research; rather it emerged toward the conclusion of our analysis. Its significance to social justice and social change, and connection to critical reflection as ideology critique in food systems, warrants further exploration.

We believe it is important to emphasize narrative inquiry as research directly with practitioners. The practitioner perspective, through storytelling, is less understood yet is needed to support the work of food systems advocates and changemakers. The role of faith-based practitioners in community food work is even less explored. Hamilton and Appleby (2009), among others, state that practitioners research has the potential to contribute to the use of practical knowledge for those both in and outside of that role. To build upon the methodologies from this practitionerfocused research, we recommend spending time building trust with the participants to allow for a deep level of reflection and openness. This will take a lengthier time commitment from participants, and may be impractical in the many situations where practitioners are extremely busy with work-related duties. Exploring ways to build this into our organizational culture of applied food systems research could be an additional avenue for this research to continue.

Lastly, Reynolds and Vince (2004) challenge the predominant notion that reflection is an individual process, and present ways of thinking about learning through reflection as a collective endeavor. Organized reflection with practitioners engages collective experience to inform individual experience (Raelin, 2004). Reynolds and Vince (2004) believe that the internal dialogue of reflection is stimulated and enhanced by external dialogue, and does not end once the external dialogue ends. Future research could better explore the impact of collective reflection on individual experience by juxtaposing collective reflection sessions with subsequent individual interviews in a long-term study of practitioners of community food work.

\section{Recommendations for Practice}

For those interested in using narratives and storytelling to learn more about their and their organization's work, we have some suggestions for next steps. First, we stress that a discussion about and allocating time for reflection in your work should be prioritized. Crafting stories and periodically discussing them as a group can enhance reflection. This would mirror the collective reflection session, which was a positive experience for the group of practitioners in this study. Further, a significant aspect of these practitioners' work is to reflect on and celebrate the small victories of the work. Although community food work challenges systemic inequality, small changes can be the building blocks to systemic change. It is important to remain positive as a practitioner and enjoy the small victories and the people along the way.

We also suggest using Whole Measurers CFS as a tool to begin with or continue the process of reflection through the planning and evaluation of programs and projects. Whole Measures CFS need not be used in its entirety. It can be useful by 
referring to specific sections as an appropriate starting point to begin reflecting on the values that inform our work. Similarly, the example of Dixon's (2015) use of counter-stories to disrupt deeply held beliefs about hunger and poverty as a pathway to mobilize charity volunteers as advocates of policy change is a practical application of critical reflection informing practice.

It is also important to point out that the narratives have numerous ways in which they can help generate opportunities for learning about community food work beyond the faith-based perspective. According to Niewolny and D'Adamo-Damery (2016), this would include appreciating the stories as personal experiences where we can learn about actual practice or strategies to put into practice. They also suggest viewing narratives as spaces of understanding that can help humanize the wickedness of the issues that inform and shape our community food work. For some, food insecurity is one such issue. In this way, we suggest that narratives not only help create understanding when read and shared, but also can generate a deeper sense of empathy for those whose lives are most affected, which in turn brings more hope and dignity to our communities. For more examples of stories of community food work that stretch across a region and address practitioner perspectives, including faith-based community food work, visit the Stories of Community Food Work in Appalachia initiative (Niewolny, 2016).

\section{Conclusion}

Community food work presents an opportunity whereby practitioners and participants alike are faced with critical issues such as racial and class inequality. This case study revealed how faith-based practitioners used critical reflection, through storytelling, to confront and begin restructuring current racial and class disparities in food systems. Such disparities are a consequence of deep-rooted power imbalances in our political and economic systems.
The role faith played in their work varied among the practitioners, from being the foundation of their involvement in the work to being an auxiliary benefit. Using Whole Measures CFS as a stimulus for critical reflection was an effective method to generate these values-based insights on community food work. Justice and fairness, especially racial and economic, were prominent themes throughout the narratives. Building strong communities emerged in the sense of forging strong, trusting relationships between the practitioners and program participants as well as between the participants themselves. By bridging racial, economic, and cultural divides, the practitioners engage with program participants who are systemically marginalized yet are full of opportunity to make the change they seek. By conducting the research in this way, the role of critical consciousness-raising is brought to the forefront, which encourages us to realize and acknowledge this marginalization and to begin dismantling systemic oppression where it connects with our community food work. Healthy people was the third most common field of practice to emerge from the narratives, and from the practitioners' collective perspectives, healthy people took on a holistic sense, including mind, body, and spirit.

To conclude, the conversation between theory and practice is a necessary element of critical practice. As we have illustrated in this study, the conversation is valuable to community food work practitioners. Storytelling is an effective approach to stimulating critical reflection. Stories can reveal new perspectives and possibilities in one's community food work as well as humanize the work itself. Blurring the line between practitioner and scholar allows for the co-creation of knowledge that is useful to inform both community food work theory and its practice. The research methods applied here can easily be transferred to other settings, revealing more about the values-based nature of community food work and its potential for enacting socially just community change.

\section{References}

Abi-Nader, J., Ayson, A., Harris, K., Herrera, H., Eddins, D., Habib, D.,... Villanueva, L. (2009). Whole measures for community food systems: V alues-based planning and evaluation. Retrieved from http://wholecommunities.org/resources/

Alkon, A. H., \& Agyeman, J. (2011). Cultivating food justice: Race, class and sustainability. Cambridge, Massachusetts: MIT Press. 
Anderson, M. D. (2008). Rights-based food systems and the goals of food systems reform. Agriculture and Human Values, 25, 593-608. http://dx.doi.org/10.1007/s10460-008-9151-z

Brookfield, S. (n.d.). Critical Incident Questionnaire. Retrieved March 16, 2016, from http://www.stephenbrookfield.com/ciq/

Brookfield, S. (1995). Becoming a critically reflective teacher. San Francisco: Jossey-Bass.

Brookfield, S. (2001). Repositioning ideology critique in a critical theory of adult learning. Adult Education Quarterly, 52(1), 7-22. http://dx.doi.org/10.1177/07417130122087368

Brookfield, S. (2009). The concept of critical reflection: Promises and contradictions. European Journal of Social Work, 12(93), 293-304. http://dx.doi.org/10.1080/13691450902945215

Brookfield, S. \& Holst, J. (2011). Radicalizing learning: Adult education for a just world. San Francisco: Jossey-Bass

Cadieux, K. V., \& Slocum, R. (2015). What does it mean to do food justice? Journal of Political Ecology, 22, 1-26. Retrieved from http://jpe.library.arizona.edu/volume 22/Cadieuxslocum.pdf

Cervero, R. M., \& Wilson, A. L. (2001). Power in practice. San Francisco: Jossey-Bass.

Clandinin, D. J., \& Connelly, F. M. (2000). Narrative inquiry: Experience and story in qualitative research. San Francisco: JosseyBass.

Coleman-Jensen, A., Nord, M., \& Singh, A. (2013). Household food security in the United States in 2012. USDA Economic Research Service. Retrieved from https://www.ers.usda.gov/webdocs/publications/45129/39937 err155.pdf?v $=42199$

Coleman-Jensen, A., Rabbitt, M. P., Gregory, C. A., \& Singh, A. (2017). Household food security in the United States in 2016 (Economic Research Report No. ERR-237). Washington, D.C.: USDA Economic Research Service. Retrieved from https://www.ers.usda.gov/publications/pub-details?pubid $=84972$

Crowe, J., \& Smith, J. (2012). The influence of community capital toward a community's capacity to respond to food insecurity. Community Development, 43(2), 169-186. https://dx.doi.org/10.1080/15575330.2011.575230

Dixon, B. (2015). Rewriting the call to charity: From food shelf volunteer to food justice advocate. Journal of Agriculture, Food Systems, and Community Development, 5(2), 71-79. http://dx.doi.org/10.5304/jafscd.2015.052.010

Emery, M., \& Flora, C. B. (2006). Spiraling-up: Mapping community transformation with community capitals. Community Development, 31(1), 19-35. http://dx.doi.org/10.1080/15575330609490152

Fisher, A. (2017). Big bunger: The unholy alliance between corporate America and anti-bunger groups. Cambridge, Massachusetts: MIT Press.

Ford, P., Johnston, B., Brumfit, C., Mitchell, R., \& Myles, F. (2005). Practice learning and the development of students as critical practitioners—some findings from research. Social Work. Education, 24(4), 391-407. http://dx.doi.org/10.1080/02615470500096910

Freire, P. (1972). Pedagogy of the oppressed. New York: Continuum International Publishing Group.

Freire, P. (1973). Education for critical consciousness (M. B. Ramos, Trans.). New York: Seabury.

Giroux, H. (2006). Academic freedom under fire: The case for critical pedagogy. College Literature, 33(4), 1-42. https://dx.doi.org/10.1353/lit.2006.0051

Guthman, J. (2008). Bringing good food to others: Investigating the subjects of alternative food practice. Cultural Geographies, 15(4), 431-447. http://dx.doi.org/10.1177/1474474008094315

Hamilton, M., \& Appleby, Y. (2009). Critical perspectives on practitioner research: Introduction to the special edition. Studies in the Education of Adults, 41(2), 107-117. https://dx.doi.org/10.1080/02660830.2009.11661576

Hamm, M. W. (2009). Principles for framing a healthy food system. Journal of Hunger and Environmental Nutrition, 4(3-4), 241-250. https://dx.doi.org/10.1080/19320240903321219

Hamm, M., \& Bellows, A. (2003). Community food security and nutrition educators. Journal of Nutrition Education and Behavior, 35(1), 37-43. https://dx.doi.org/10.1016/S1499-4046(06)60325-4

hooks, b. (1994). Teaching to transgress: Education and the practice of freedom. New York: Routledge.

Landis, R. (2015) Community food work as critical practice: A faith-based perspective. Unpublished master's thesis, Virginia Polytechnic and State University, Blacksburg, Virginia. Retrieved from https://vtechworks.lib.vt.edu/bitstream/handle/10919/56581/Landis RD T 2015.pdf?sequence=1 
Lather, P. (1991). Getting smart: Feminist research and pedagogy with/in the postmodern. New York: Routledge.

Mann, P., \& Lawrence, K. (1998). Rebuilding our food system: The ethical and spiritual challenge. Earth Ethics, 1998 (Spring/Summer), 21-26.

Mathie, A., \& Cunningham, G. (2003). From clients to citizens: Asset-based community development as a strategy for community-driven development. Development in Practice, 13(5), 474-486. http://dx.doi.org/10.1080/0961452032000125857

McGovern, Dole \& Messer. (2005). Ending hunger now. Minneapolis, MN: Fortress Press.

Morrow, R. A. \& Torres, C. A. (2002). Reading Freire and Habermas: Critical pedagogy and transformative social change. Amsterdam, New York: Teachers College Press.

Niewolny, K. (2016). Stories of community food work in Appalachia: Opening space for storytelling and learning. Blacksburg: Virginia Tech. Retrieved from http://blogs.lt.vt.edu/niewolny/

Niewolny, K., \& D’Adamo-Damery, P. (2016). Learning through story as political praxis: The role of narratives in community food work. In J. Sumner (Ed.), Learning, food, and sustainability: Sites for resistance and change (pp. 113-132). New York: Palgrave/Macmillan.

Peters, S. J., Grégoire, H., \& Hittleman, M. (2004). Practicing a pedagogy of hope: Practitioner profiles as tools for grounding a guiding collective reflection in adult, community, and youth development education. In M. Reynolds \& R. Vince (Eds.), Organizing reflection (pp. 194-219). Hampshire, England: Ashgate.

Peters, S. J., \& Hittleman, M. J. (Eds.). (2003). We grow people: Profiles of extension educators. Ithaca, NY: Cornell Cooperative Extension.

Poppendieck, J. (1998). Sweet charity? Emergency food and the end of entitlement. New York: Penguin Group.

Raelin, J. (2004). Forward. In M. Reynolds \& R. Vince (Eds.), Organizing reflection (pp. xi-xii). Hampshire, England: Ashgate.

Ramírez, M. M. (2014). The elusive inclusive: Black food geographies and racialized food spaces. Antipode, 47(3), 748769. http://dx.doi.org/10.1111/anti.12131

Reynolds, M., \& Vince, R. (2004). Organizing reflection. Hampshire, England: Ashgate.

Richmond, H. J. (2002). Learners' lives: A narrative analysis. The Qualitative Report, 7(3). Retrieved June 1, 2015, from http://www.nova.edu/ssss/QR/QR7-3/richmond.html

Rosenberger, N., Richards, L., Nevin Gifford, L., \& Gossen, K. (2006). From our own soil: A community food assessment Benton County, Oregon, and its foodshed. 2006. Portland: Ecumenical Ministries of Oregon. Retrieved from http://www.emoregon.org/pdfs/IFFP/CorvallisFoodAssessmentReport-logo.pdf

Schneider, J., Wittberg, P., Unruh, H., Sinha, J., \& Belcher, J. (2011). Comparing practical theology across religions and denominations. Review of Religious Research, 52(4), 405-426.

Slocum, R. (2006). Anti-racist practice and the work of community food organizations. Antipode, 38(2), $327-349$. http://dx.doi.org/10.1111/j.1467-8330.2006.00582.x

Slocum, R. (2007). Whiteness, space and alternative food practice. Geoforum, 38, 520-533. https://dx.doi.org/10.1016/j.geoforum.2006.10.006

Tanaka, K., Indiano, E., Soley, G., \& Mooney P. H. (2015). Building capacity for community food work: The geographic distribution of USDA community food projects competitive grant program. Journal of Agriculture, Food Systems, and Community Development, 5(3), 97-111. http://dx.doi.org/10.5304/jafscd.2015.053.006

Thompson, N., \& Pascal, J. (2012). Developing critically reflective practice. Reflective Practice: International and Multidisciplinary Perspectives, 12(2), 311-325. http://dx.doi.org/10.1080/14623943.2012.657795

Todd, N. R. (2012). Religious networking organizations and social justice: An ethnographic case study. American Journal of Community Psychology, 50, 229-245. http://dx.doi.org/10.1007/s10464-012-9493-y

Whitney, D., \& Cooperrider, D. (1998). The appreciative inquiry summit: Overview and applications. Employment Relations Today, 25(2), 17-28. http://dx.doi.org/10.1002/ert.3910250203

Winne, M. (2008). Closing the food gap: Resetting the table in the land of plenty. Boston, Massachusetts: Beacon Press. 